\title{
Bacteriological analysis, antimicrobial susceptibility and detection of 16S rRNA gene of Helicobacter pylori by PCR in drinking water samples of earthquake affected areas and other parts of Pakistan
}

\author{
Rasheed, F., ${ }^{*}$ Khan, A. and Kazmi, S. U. \\ Immunology and Infectious Disease Research Laboratory (IIDRL), Department of Microbiology, \\ University of Karachi, Karachi, Pakistan. \\ E-mail: fro hpl@hotmail.com
}

Received 22 May 2009; received in revised form 2 July 2009; accepted 7 July 2009

\begin{abstract}
In Pakistan, clean drinking water is not available to most of the population. Main source of drinking water in Hazara, Azad Jammu and Kashmir-Pakistan is underground and spring water, due to earthquake water reservoirs in these areas were immensely contaminated. Moreover, drinking water treatment and proper sanitary facilities were also lacking. This study was conducted to analyze the quality of drinking water available in most of the cities of Pakistan including earthquake hit areas. For this purpose, 112 water samples were collected and analyzed by membrane filtration method. Microbial isolates were identified using QTS-10 and biochemical tests. Almost all samples were found to be contaminated but in earthquake affected areas quality of drinking water was substandard than other areas of Pakistan. Results revealed the detection of following bacterial pathogens among the water samples: Enterobacter sp., Klebsiella sp., Stenotrophomonas sp., Salmonella sp., Proteus sp., Edwardsiella tarda, Pseudomonas aeruginosa, Vibrio parahaemolyticus, Vibrio cholerae, Escherichia coli, Acinetobacter baumanii, Aeromonas hydrophila, Citrobacter freundii, Shigella dysenteriae, Staphylococcus aureus, Staphylococcus sp. and Streptococcus sp. Furthermore, these bacterial isolates were found to be resistant to ampicillin (32.1\%), amoxicillin (30.4\%), sulphometoxazole $(20.5 \%)$ and cefaclor (31.3\%). All drinking water samples were analyzed for 16S rRNA gene of Helicobacter pylori by using PCR, however no positive result was found in these samples. Based on our results it is suggested that authorities should pay attention to supply safe water and proper sanitary facilities to avoid epidemics of infectious diseases in future.
\end{abstract}

Keywords: earthquake affected areas, drinking water, antimicrobial resistance, $H$. pylori, PCR

\section{INTRODUCTION}

Clean drinking water, a basic necessity is available only to a smaller proportion of Pakistani population. Due to mismanagement, bad civic conditions and natural disasters in developing countries like Pakistan there is a very high ratio of underground water contamination. Contaminated drinking water plays a key role in the spread of water-borne infectious diseases. The condition of ground water became shoddier when strong earthquake hit Hazara, Azad Jammu and Kashmir (AJK)Pakistan in 2005 killing more than 87,000 and leaving over 3.3 million people homeless. According to WHO guideline for bacteriological quality, potable water should be free from indicators of fecal pollution. Water to be used for drinking and cooking purposes must be free from turbidity, colour, odour and objectionable tastes as well as from disease causing organisms and organic and inorganic substances which may produce adverse physiological effects (Sciortino, 1993).

Majority of water-borne bacterial infections are spread by Helicobacter pylori, Campylobacter jejuni, Enterotoxigenic Escherichia coli, Salmonella typhi and Vibrio cholerae. In Pakistan water-borne diseases are a major problem, which contributes to a number of deaths every year. Repeated episodes of diarrhea occurred by drinking contaminated water results in malnutrition leading to increased susceptibility to diseases. Year 2005 was a worst year for Pakistanis from epidemic point of view. Three major gastrointestinal outbreaks occurred in Karachi and Hyderabad. More than 500 people suffered from gastrointestinal diseases in Hyderabad where 3 of them were died. Another outbreak of water-borne diarrhea occurred in Essa Nagri, a colony of Karachi that claimed 2 lives with more than 200 suffered from the condition which emerged again with severity when water-borne diarrhea claimed another 9 precious lives including 3 innocent children and affected more than 800 people.

Various drinking water sources harbor multiple antibiotic resistant bacteria suggesting that water contaminated with antibiotic resistant bacteria may be a primary source of severe infectious diseases (Armstrong et al., 1981). Infection with $H$. pylori is estimated to be $40-$ $70 \%$ worldwide (Brown, 2000). H. pylori is included in the Candidate Contaminant List compiled by the US Environmental Protection Agency (http://www.epa.gov). This list includes drinking water contaminants that are a priority for research, monitoring and possible future 
regulation. The risk of acquisition of the infection is especially high among those people living in developing countries (Al-Moagel et al., 1990; Malaty et al., 1996). The risks of acquisition of $H$. pylori infection are multifactorial that may include interaction with potentially contaminated environmental sources, such as local drinking water, swimming in rivers and the ingestion of fecally contaminated vegetables (Begue et al., 1998; Sazaki et al., 2001). Detection of $H$. pylori in drinking water strengthens the argument for a possible route of transmission.

Main source of drinking water in earthquake affected areas was underground, badly contaminated due to earthquake. There is no proper sewage and water purification system in highly populated and big cities of Pakistan that may be the source of contamination in drinking water. So, the present study was designed to determine bacteriological prevalence, antibiotic susceptibility in drinking water of earthquake affected areas and major cities of Pakistan and to determine whether the acquisition of $H$. pylori was associated with water-borne infection in Pakistan or not.

\section{MATERIALS AND METHODS}

\section{Study sites}

Samples were collected from the earthquake affected areas of Hazara, Azad Jammu and Kashmir (AJK)Pakistan including Mansehra, Abbottabad, Balakot, Ghari Habibullah, Muzaffarabad and other major cities including Karachi, Lahore, Sargodha, Sahiwal, Islamabad, Rawalpindi and Swat.

\section{Sample Collection}

\section{Source of water}

Source of water in earthquake affected areas was spring and underground water while in cities the source was common water reservoirs. One hundred and twelve water samples were collected according to standard procedures using $500 \mathrm{~mL}$ polyethylene sterile sampling bottles containing $10 \%$ sodium thiosulfate. Before collection the tape was allowed to flush for 5 to $10 \mathrm{~min}$. These samples were then transported to the Immunology and Infectious Disease Research Laboratory (IIDRL), Department of Microbiology, University of Karachi in a light proof insulated box containing ice packs and analyzed within 24 $\mathrm{h}$ for different microbiological parameters. The details of the parameters taken under consideration were as follows.

\section{MF Procedure}

Each sample was filtered through a $47 \mathrm{~mm}$ diameter, 0.45 $\mu \mathrm{m}$ pore size cellulose acetate MF grid (Millipore Corp, Bedford-USA) held in a filtration unit. Each filtration series was began with steam sterilized filtration units. A $100 \mathrm{~mL}$ of each sample was membrane filtered and the filters were transferred to the surface of MacConkey agar and
Muller Hinton agar (Oxoid, Basingstoke-UK) plates. Plates were incubated at $37{ }^{\circ} \mathrm{C}$ for $24 \mathrm{~h}$. Different types of colonies were picked and identified at species level using QTS-10 (DESTO Laboratories, Karachi-Pakistan) and biochemical tests.

\section{Antimicrobial susceptibility testing}

The standard Kirby Bauer disk diffusion method (Bauer et al., 1966) was used to develop the antimicrobial susceptibility profile of all bacterial isolates against eight antimicrobial agents including ampicillin (AMP), amoxicillin (AMC), gentamicin (CN), ofloxacin (OFX), sulphometoxazole (SXT), cefaclor (CEC), amikacin (AK) and piperacillin tazobactam (TZP). These antimicrobial agents were chosen on the basis of their importance in treating human or animal bacterial infections or their use as feed additives to promote growth in animals and to provide diversity in representation of different antimicrobial classes (Krumperman, 1983). A Muller Hinton broth (Oxoid, Basingstoke-UK) tube was inoculated with isolated bacterial culture and incubated to the turbidity of a $0.5 \mathrm{McF}$ arland standard and then swabbed onto a 150 $\mathrm{mm}$ Mueller Hinton agar plate. Eight commercially prepared antimicrobial discs (Oxoid, Basingstoke-UK) were dispensed onto the inoculated plates. These plates were incubated at $35{ }^{\circ} \mathrm{C}$ for 18 to $20 \mathrm{~h}$. The diameter of the clear zones of growth inhibition around the antimicrobial discs including the $6 \mathrm{~mm}$ disc diameter was measured in millimeters.

\section{DNA Extraction}

DNA was extracted by using ethanol precipitation method from 112 drinking water samples. Briefly water samples (5 $\mathrm{mL}$ ) were centrifuged initially for 2 min at low speed $(1,000$ rpm) in an eppendorf microcentrifuge tube to precipitate debris. The supernatant was transferred into a fresh tube and centrifuged at high speed $(14,000 \mathrm{rpm})$ to collect the suspended microorganisms. The pellet was resuspended in $80 \mu \mathrm{L}$ of PK buffer ( $\mathrm{pH} 7.5$ containing $0.5 \mathrm{M}$ EDTA and $4 \mathrm{M} \mathrm{NaCl}), 1 \%$ SDS and proteinase- $\mathrm{K}(0.5 \mathrm{mg} / \mathrm{mL})$. The mixture was incubated at $55^{\circ} \mathrm{C}$ for $1 \mathrm{~h}$ and then $6 \mathrm{M} \mathrm{NaCl}$ was added and vortexed for $1 \mathrm{~min}$ and centrifuged at $14,000 \mathrm{rpm}$ for $5 \mathrm{~min}$. The nucleic acids were precipitated by adding absolute ethanol, harvested by centrifugation and resuspended in $100 \mu \mathrm{L}$ of TE buffer $(\mathrm{pH} 7.5$ containing $10 \mathrm{mM}$ Tris and $1 \mathrm{mM}$ EDTA). Samples were stored at $4{ }^{\circ} \mathrm{C}$ until tested.

\section{PCR}

H. pylori specific primers against 16S rRNA genes were amplified. Target site, amplicon size, primer name and sequence and PCR temperature program are shown in Table 1. All PCR reagents were supplied by Promega Corporation (Madison-USA) and primers by Alpha DNA (Montreal-Canada). Each PCR reaction consisted of $1 \mathrm{X}$ reaction buffer, $1.5 \mathrm{mM} \mathrm{MgCl} 2,200 \mu \mathrm{M}$ each dNTPs, 10 pmol of each primer, $1.5 \mathrm{U}$ Taq DNA polymerase and $5 \mu \mathrm{L}$ 
of target DNA (final reaction volume of $25 \mu \mathrm{L}$ ). PCR products were electrophoresed through $1 \%$ agarose and ethidium bromide staining.

Table 1: Conditions for PCR method

\begin{tabular}{|c|c|c|}
\hline $\begin{array}{l}\text { Amplicon } \\
\text { size (bp) }\end{array}$ & $\begin{array}{l}\text { Primer names and } \\
\text { sequence }\end{array}$ & $\begin{array}{c}\text { PCR temperature } \\
\text { program }\end{array}$ \\
\hline \multirow[t]{2}{*}{210} & $\begin{array}{l}\text { JW } 22 \text { (forward primer) } \\
\text { (5'-AAC TGG AGG } \\
\text { AAG GTG GGG AY-3') }\end{array}$ & $\begin{array}{l}95^{\circ} \mathrm{C}, 5 \mathrm{~min} ; \\
95^{\circ} \mathrm{C}, 30 \mathrm{~s} ; 65^{\circ} \mathrm{C}, 30 \mathrm{~s} ; \\
72^{\circ} \mathrm{C}, 30 \mathrm{~s} ;(30 \text { cycles }) \\
72^{\circ} \mathrm{C}, 5 \mathrm{~min}\end{array}$ \\
\hline & $\begin{array}{l}\text { JW } 23 \text { (reverse primer) } \\
\text { (5'-AYG ACG TCA AGT } \\
\text { CMT CAT GG-3') }\end{array}$ & \\
\hline
\end{tabular}

*Target site was $16 \mathrm{~S}$ rRNA gene

\section{RESULTS}

In this study 112 drinking water samples were analyzed to determine the bacteriological quality. Large variety of bacterial pathogens including Enterobacter sp., Klebsiella sp., Stenotrophomonas sp., Salmonella sp., Proteus sp., $E$. tarda, $P$. aeruginosa, V. parahaemolyticus, V. cholerae, E. coli, A. baumanii, A. hydrophila, C. freundii, $S$. dysenteriae, $S$. aureus, Staphylococcus $\mathrm{sp}$. and Streptococcus sp. were isolated from drinking water samples.

Figure 1 summarizes bacterial population isolated from drinking water samples of earthquake affected areas including Mansehra, Abbottabad, Balakot, Ghari Habibullah and Muzaffarabad, while summary of bacterial population isolated from drinking water samples of Karachi is shown in Figure 2, Lahore, Sahiwal, Sargodha in Figure 3 and Islamabad, Rawalpindi, Swat in Figure 4.

Bacterial isolates were resistant to ampicillin (32.1\%), while resistance to others was as follow: amoxicillin $(30.4 \%)$, gentamicin (3.6\%), ofloxacin (1.8\%), sulphometoxazole $(20.5 \%)$, cefaclor $(31.3 \%)$, amikacin (1\%) and piperacillin tazobactam (1.8\%) (Table 2).

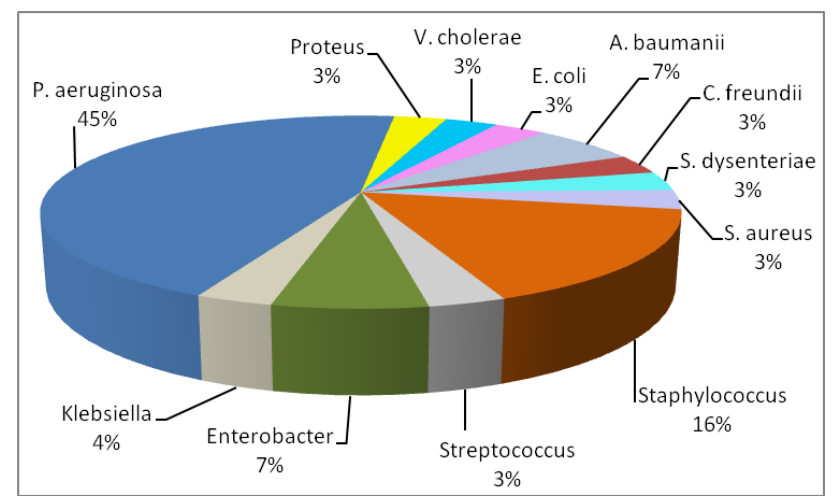

Figure 1: Bacterial populations isolated from drinking water samples of earthquake affected areas

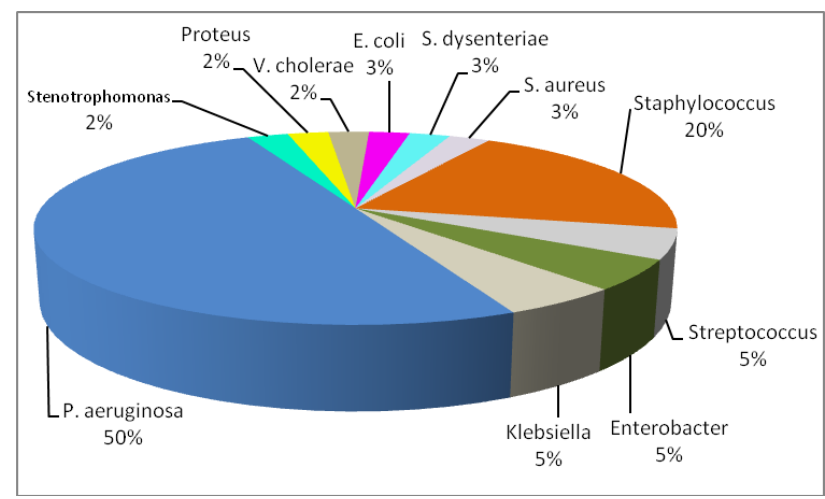

Figure 2: Distribution of bacterial isolates in drinking water samples of Karachi

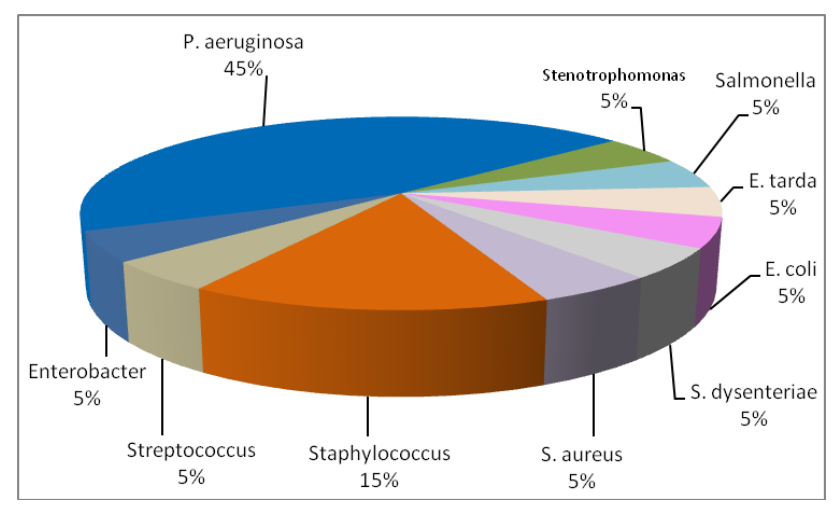

Figure 3: Bacterial population isolated from drinking water samples of Lahore, Sargodha and Sahiwal

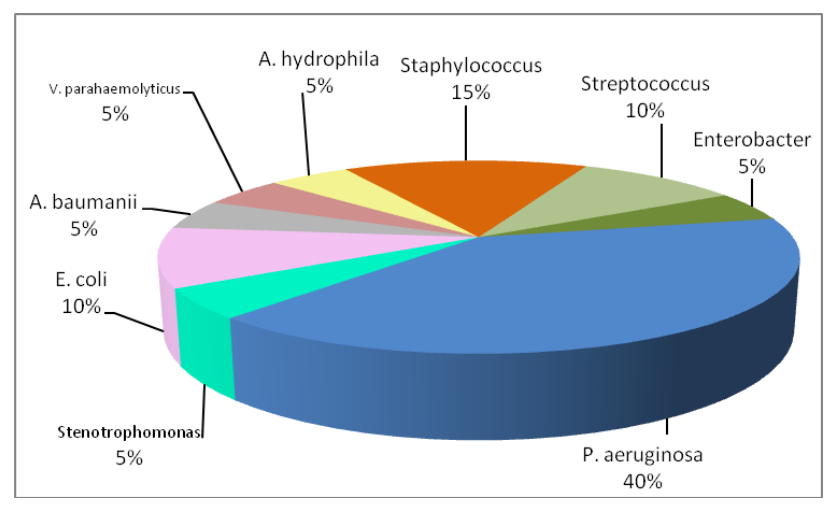

Figure 4: Distribution of bacterial population isolated from drinking water samples of Islamabad, Rawalpindi and Swat

Result of antimicrobial susceptibility is shown in Figure 5. One hundred and twelve drinking water samples were analyzed for $H$. pylori using $16 \mathrm{~S}$ rRNA PCR. All samples were negative for 16S rRNA gene. 
Table 2: Results of antimicrobial resistance

\begin{tabular}{lc}
\hline Antimicrobial Agents & $\begin{array}{c}\text { No. of resistant isolates } \\
\text { of drinking water (\%) }\end{array}$ \\
\hline ampicillin & $36(32.1 \%)$ \\
amoxicillin & $34(30.4 \%)$ \\
gentamicin & $4(3.6 \%)$ \\
ofloxacin & $2(1.8 \%)$ \\
sulphometoxazole & $23(20.5 \%)$ \\
cefaclor & $35(31.3 \%)$ \\
amikacin & $1(1 \%)$ \\
piperacillin tazobactam & $2(1.8 \%)$. \\
\hline
\end{tabular}

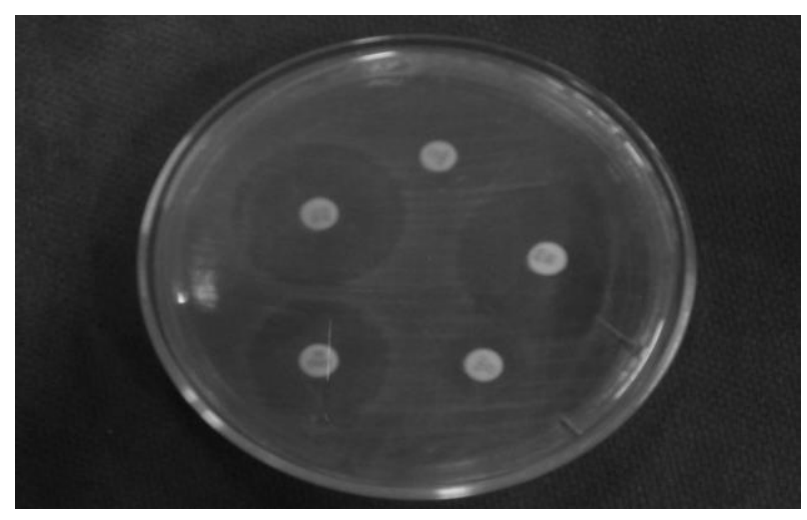

Figure 5: Result of amikacin, ofloxacin, gentamicin susceptible and amoxicillin, cefaclor resistant Proteus sp. isolated from drinking water sample of Karachi

\section{DISCUSSION}

The presence of various bacterial pathogens in water provided for human consumption in earthquake affected areas and major cities of Pakistan, would nevertheless point to presence of either an inadequate purification system or a subsequent contamination in water and could furthermore constitute an important public health and hygiene issue. The relatively high incidence of resistance for AMP, AMC, SXT and CEC among bacterial isolates was observed, but these were to some extent resistant to AK, CN, OFX and TZP.

The increased incidence of resistance among bacterial isolates to specific antibiotics has been reported by various authors world over (Magee et al., 1991; McKeon et al., 1995; Sabry et al., 1997; Boon and Cattanach, 1999). Water-borne infection of $H$. pylori would be of particular concern in regions of the world where water quality is poor, and may be one reason for the difference in prevalence of $H$. pylori between developed and developing countries. Both polymerase chain reaction and fluorescent antibody staining have been used successfully for the detection of $H$. pylori in clinical or environmental samples (Rivera et al., 1991; Rodewig et al., 1992; Husson et al., 1993; Sciortino, 1993; Handwerker et al., 1995; Hulten et al., 1996; Hulten et al., 1998). However, no accepted standard procedure for either of these methods currently exists and both have the potential for false positive results (Hegarty et al., 1999). In this study $H$. pylori was not detected from drinking water samples. This might be due to low template concentration used in PCR reaction for detection of $H$. pylori.

The antimicrobial resistance detected in this study would underscore the necessity of promoting the judicious use of antimicrobial agents within the public domain while the detection of potentially dangerous bacterial pathogens in drinking water of Hazara, AJK and different cities of Pakistan would point to the need of implementation of a program of active vigilance at country level aimed at ensuring the quality of drinking water in the system as well as to the end users.

\section{ACKNOWLEDGEMENT}

We gratefully acknowledge the assistance of Amber Farroqui, Mehmooda Kazmi and Safwan Ullah Khan in this study.

\section{REFERENCES}

Al-Moagel, M. A., Evans, D. G., Abdulghani, M. E., Adam, E., Evans, D. J., Malaty, H. M. and Graham, D. Y. (1990). Prevalence of Helicobacter pylori (formerly Campylobacter) infection in Saudia Arabia and comparison of those with and without upper gastrointestinal symptoms. American Journal of Gastroenterology 85, 944-948.

Armstrong, J. L., Shigeno, D. S., Calomiris, J. J. and Seidler, R. J. (1981). Antibiotic resistant bacteria in drinking water. Applied and Environmental Microbiology 42, 277-283.

Bauer, A. W., Kirby, W. M. M. M., Sherris, J. C. and Turck, M. (1966). Antibiotic susceptibility testing by a standardized single disk method. American Journal of Clinical Pathology 45, 493-496.

Begue, R. E., Gonzales, J. L., Correa, G. H. and Tang, S. C. (1998). Dietary risk factors associated with the transmission of Helicobacter pylori in Lima, Peru. American Journal of Tropical Medicine and Hygiene $59,637-640$.

Boon, P. I. and Cattanach, M. (1999). Antibiotic resistance of native and faecal bacteria isolated from rivers, reservoirs and sewage treatment facilities in Victoria, South-Eastern Australia. Letters in Applied Microbiology 28, 164-168.

Brown, L. M. (2000). Helicobacter pylori: Epidemiology and routes of transmission. Epidemiology Reviews 22, 283-297.

Handwerker, J., Fox, J. G. and Schauer, D. B. (1995). Detection of Helicobacter pylori in drinking water using polymerase chain reaction amplification. $I n: 95^{\text {th }}$ 
General Meeting of the American Society for Microbiology. Washington, DC. pp. 435.

Hegarty, J. P., Dowd, M. T. and Baker, K. H. (1999). Occurrence of Helicobacter pylori in surface water in the United States. Journal of Applied Microbiology 87, 697-701.

Hulten, K., Enroth, H., Nystrom, T. and Engstrand, L. (1998). Presence of Helicobacter species DNA in Swedish water. Journal of Applied Microbiology 85, 282-286.

Hulten, K., Han, S. W., Enroth, H., Klein, P. D., Opekun, A. R., Gilman, R. H., Evans, D. G., Engstrand, L., Graham, D. Y. and El-Zaatari, F. A. (1996). Helicobacter pylori in the drinking water in Peru. Gastroenterology 110, 1031-1035.

Husson, M. O., Gottrand, F., Turck, D. and Leclerc, $\mathbf{H}$. (1993). Detection of $H$. pylori in saliva using a monoclonal antibody. Zentralblatt für Bakteriologie: International Journal of Medical Microbiology 279, 466-471.

Krumperman, P. H. (1983). Multiple antibiotic resistance indexing of Escherichia coli to identify high risk sources of fecal contamination of foods. Applied and Environmental Microbiology 46, 165-170.

Magee, A. M. and Quinn, J. P. (1991). Antibiotic resistance in the bacteria of a remote upland river catchment. Letters in Applied Microbiology 13, 145149.

Malaty, H. M., Kim, J. G., Kim, S. D. and Graham, D. Y. (1996). Prevalence of Helicobacter pylori infection in Korean children: inverse relation to socioeconomic status despite a uniformly high prevalence in adults. American Journal of Epidemiology 143, 257-262.

McKeon, D. M., Calabrese, J. P. and Bissonnette, G. K. (1995). Antibiotic resistant Gram negative bacteria in rural groundwater supplies. Water Research 29, 1902-1908.

Rivera, E., Lopez, V. Y., Luqueno, V. and Ruiz, P. G. M. (1991). Indirect immunofluorescence assay for detection of Helicobacter pylori in human gastric mucosal biopsies. Journal of Clinical Microbiology 29, 1748-1751.

Rodewig, U., Bemb, W., Bitter, S. D., Elsheikh, M., Fritsch, S., Glann, C. E., Soudah, B., Varrentrapp, M., Wagner, S. and Bar, W. (1992). Evaluation of a monoclonal antibody for detection of Helicobacter pylori in a direct immunofluorescence test. European Journal of Clinical Microbiology and Infectious Disease 11, 737-739.

Sabry, S. A., Ghozian, H. A. and Abou-Zeid, D. M. (1997). Metal tolerance and antibiotic resistance patterns of a bacterial population isolated from sea water. Journal of Applied Microbiology 82, 245-252.

Sazaki, K., Tajiri, Y., Sata, M., Fujii, Y., Matsubara, F., Zhao, M., Shimizu, S., Toyonaga, A., Tanikawa, K. (2001). Helicobacter pylori in the natural environment. Scandinavian Journal of Infectious Diseases 31, 275279.

Sciortino, C. V. J. (1993). An immunofluorescent stain for Helicobacter pylori. Hybridoma. Guidelines for drinking water quality. World Health Organization, Geneva. 12, 333-342. 